\title{
BIODIVERSITY AND ECOLOGY OF FAUNA IN PERCOLATING WATER IN SELECTED SLOVENIAN AND ROMANIAN CAVES
}

\author{
BIODIVERZITETA IN EKOLOGIJA FAVNE V PRENIKLI VODI \\ IZBRANIH SLOVENSKIH IN ROMUNSKIH JAM
}

\author{
Oana T. MOLDOVAN ${ }^{1}$, Tanja PIPAN² ${ }^{2}$ Sanda IEPURE ${ }^{1}$, Andrej MIHEVC ${ }^{2} \&$ Janez MULEC ${ }^{2}$
}

\begin{abstract}
UDC 574.5:551.44(497.4+498)

Oana T. Moldovan, Tanja Pipan, Sanda Iepure, Andrej Mihevc \& Janez Mulec: Biodiversity and ecology of fauna in percolating water in selected Slovenian and Romanian caves Biodiversity and ecology of fauna in percolating water from Slovenian and Romanian caves was studied. Research focused on unravelling the community structure of epikarst fauna, which is carried away by the trickles of percolating water from the epikarst and vadose zones. The major part of the fauna found in percolating water is represented by copepods. This fauna, originating in the epikarst, was analysed and by means of the systematic sampling and observation the same groups of animals were found in Slovenian and Romanian caves. Differences among caves and sampling points indicate that epikarst is a heterogenous habitat. Relationship between faunal richness and the physical characteristics of the water was found. Correlation between surface geomorphology and fauna in percolating water was statistically significant in the Postojna cave system. Key words: karst, epikarst, percolating water, speleobiology, fauna, Copepoda.
\end{abstract}

Izvleček

UDK 574.5:551.44(497.4+498)

Oana T. Moldovan, Tanja Pipan, Sanda Iepure, Andrej Mihevc \& Janez Mulec: Biodiverziteta in ekologija favne v prenikli vodi izbranih slovenskih in romunskih jam

$\mathrm{V}$ prenikli vodi iz slovenskih in romunskih jam smo proučevali biodiverziteto in ekologijo favne. V raziskavi smo se osredotočili na proučevanje združbe epikraške favne, ki jo odnašajo curki prenikle vode iz epikraške in nezasičene cone. Največji delež organizmov v prenikli vodi zavzemajo ceponožni raki. Na podlagi sistematičnega vzorčenja in opravljenih analiz smo v jamah slovenskega in romunskega krasa ugotovili prisotnost enakih skupin organizmov. Razlike med jamami in posameznimi vzorčnimi mesti nakazujejo, da je epikras heterogeni habitat. Ugotovili smo statistično značilno povezavo med prisotnostjo določenih skupin organizmov in fizikalnimi parametri vode. Korelacija med površinsko geomorfologijo Postojnskega jamskega sistema in številom ceponožnih rakov v prenikli vodi je bila statistično značilna.

Ključne besede: kras, epikras, prenikajoča voda, speleobiologija, favna, Copepoda.

\section{INTRODUCTION}

The upper layer of the unsaturated zone called epikarst is the interface zone between soil and rock in karst landscape and is characterized by small fractures and solution pockets that may or may not be filled with water (Williams 1983). It is an important zone for the transport of pollutants, an important water storage site (Petrič
2002, Trček 2003), and a habitat of high diversity of invertebrates (Pipan 2005). There is a complex and diverse aquatic community of microinvertebrates in the epikarst and vadose zone, including a rich crustacean fauna, especially copepods (Pipan 2005). By contrast with many subsurface habitats with large voids, the epikarst habitat

${ }^{1}$ Romanian Academy, Institutul de Speologie “Emil Racovitza”, Department of Cluj, Clinicilor 5, 400006 Cluj-Napoca, Romania, E-mail: oanamol@hasdeu.ubbcluj.ro

${ }^{2}$ Karst Research Institute, Scientific Research Centre of the Slovenian Academy of Sciences and Arts, Titov trg 2, p.p. 59, SI-6230, Postojna, Slovenia, E-mail: pipan@zrc-sazu.si

Received/Prejeto: 08.10.2007 
is poorly integrated; catchment areas extend only a hundred or so meters (Pipan \& Culver 2007).

In the last three years through the joint research project between Slovenia and Romania our basic research focused on study of biodiversity and ecology of fauna in trickles of percolation water. Research was done in selected caves in Slovenian Classical Karst and Romanian Western Carpathians. It is worth mentioning that both research groups benefited from the interesting results that came from the collaboration. The new approach of investigation of cave-dwelling fauna brought also a new and improved understanding of the biodiversity of the groundwater and opened new horizon of the investigation which will be upgraded in the future. Due to inaccessibility of the unsaturated zone it is impossible to examine directly the biological processes within the epikarst and vadose zone. On the other hand it is relatively easy to study them indirectly by taking samples of water which drips down the cave walls or seeps from the cave ceiling. Trickles represent the transition between two habitats: the inaccessible epikarst together with vadose zone and pools of water occurring in cave passages.
The first investigations on fauna of fissures were done by Rouch (1968), Delay (1968), and many other authors as mentioned in Sket et al. (2003), but the first large scale study of fauna from epikarst and vadose zone started in 2000 in Slovenia. By the end of year 2005, 51 copepod species and subspecies were recorded in six caves; out of 32 are stygobionts (Pipan 2005). Many of these species are endemic to Slovenia and frequently even to a single site. Study of the fauna in epikarst water was later done in a cave system in West Virginia, U.S.A. (Pipan \& Culver 2005, Pipan et al. 2006) and in Spain (Camacho et al. 2006). In Romania a similar study started in 2005 with the investigation of fauna in percolating water in caves of the Western Carpathians.

Due to the numerous newly discovered species, and little knowledge about the biodiversity and ecology of fauna from percolating water we continued with sampling and investigations. In this paper we report on the results of fauna from percolation water collected in two Slovenian and three Romanian caves. Copepod community composition, population dynamics of fauna in percolating water and its relation to the surface geomorphology and chemistry of water are discussed.

\section{MATERIAL AND METHODS}

A one-year field study was conducted in two caves in Slovenia - Planinska jama and Postojnska jama and in three caves in Romania - Peştera Ungurului, Peştera Vântului and Peştera Vadu-Crişului (Fig. 1).

Postojna and Planina caves are part of the Postojna-Planina cave system which consists of approximately $23 \mathrm{~km}$ of surveyed passages (17 in Postojna cave and 6 in Planina cave connected by $2 \mathrm{~km}$ of flooded passage), developed in Upper Cretaceous carbonate rocks (Šebela 1995). The cave system is the most diverse cave in the world (Culver \& Sket 2000). The Pivka River sinks near the Postojna cave entrance, and flows towards the Planina cave where joins with the other stream Rak and exits at Planina cave entrance. The land over the cave is forested, and the Pivka River drains land with a variety of uses, including forest and agriculture, as well as several small towns. The area over the cave system itself is approximately $20 \mathrm{~km}^{2}$. Samples were taken from 5 drips in Planina cave and from 10 drips in Postojna cave (see Pipan [2005] for locations in Postojna cave). In Planina cave 5 sampled drips were at a distance of $18 \mathrm{~m}$ between the first and the last drip, while in Postojna cave the first three sampled drips were within $125 \mathrm{~m}$ and the distance between the third and the tenth drip was $1 \mathrm{~km}$. In Posto- jna cave sampling was done monthly from April to October 2000, and in Planina cave from April 2004 to December 2005.

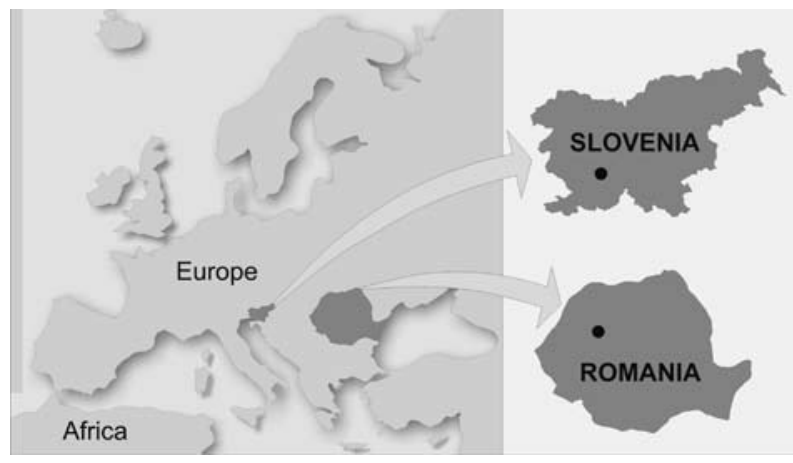

Fig. 1: Geographical location of studied caves (black dots on the right) in Slovenia and Romania.

Ungurului, Vântului and Vadu-Crişului caves belong to the Crişul Repede basin, in north-western Romania. Ungurului and Vântului caves are developed in Ladinian (middle Triassic) limestone, while Vadu-Crişului cave is in Barremian (Cretaceous) limestone. The three caves are near to each other, covered by soil and vegetation repre- 
sented by deciduous forests and pastures. The area was intensively exploited for fireclay and accidental leakage can happen in the first two caves. Vântului is the longest cave in Romania (about $50 \mathrm{~km}$ ) and the two others are among the best known show caves of Transylvania. Sampling stations were established near the entrance, on the active passage in the Vântului cave and along their entire lengths for the Ungurului and the Vadu-Crişului caves. All three caves have subterranean water courses, more important in Vântului and Vadu-Crişului. Sampling points were established where percolation is permanent or quasi-permanent along the year and collecting of accumulated material was done according to the activity of trickles, and accessibility in one case (Vântului cave). In Ungurului cave, with a development of approximate 1.5 $\mathrm{km}$ and a large entrance (32/ $22 \mathrm{~m})$, samples were taken from 4 sites, during the period March 2006 - June 2007. In Vântului cave samples were taken at the base level, near the entrance in 2 sites (April 2005 - May 2006) and in Vadu-Crişului cave percolation water was sampled in 3 sites along the main gallery of $1 \mathrm{~km}$, in 2007 (January - June).

Sampling of percolation water fauna in both countries was done in the same way. Drips were collected directly and simple sampling devices developed by Pipan $(2003,2005)$ were used to collect water and invertebrates. Dripping water was directed into a plastic container and filtered through a net mesh size $60 \mu \mathrm{m}$. Drip rates were measured only in Slovenian caves by collecting water under drips in a graduated cylinder for timed intervals. Samples were sorted in a laboratory using a dissecting microscope and only Copepoda specimens were identified to species from Postojna cave and Cyclopoida species from Romanian caves. Temperature $\left({ }^{\circ} \mathrm{C}\right)$, conductivity $\left(\mu \mathrm{Scm}^{-1}\right)$ and $\mathrm{pH}$ were measured in situ by a conductivity meter (LF 91, WTW), pH meter (323, WTW), and Combo multi-parameter Hanna Instruments.

Canonical correpondence analysis was used to correlate data on abundance of different fauna groups in five studied caves and measured physico-chemical parameters, as was used in the previous studies (Pipan 2003, 2005). Analysis was run by the program XLSTAT 2007. Spearman correlation test was performed to determine the relationship between copepod abundance versus drip rate in Slovenian caves.

To establish if a relationship between the density of the dolinas above the Postojna cave system and fauna abundance in percolation water exists, the outer edge of dolinas was defined according to the 1:5000 maps and personal observations of one of us (A. M.). Six frames of $0.12 \mathrm{~km}^{2}$ were virtually defined on the surface projection of the Postojna system. The total surface of dolinas in each frame was digitized and measured with Didger 3.05 software. Except one of the frames all others included sampling stations for percolating water. The sum of dolinas' surface and the fauna abundance of the corresponding sampling station(s) of each frame were than correlated.

\section{RESULTS}

The groups of fauna found in the studied caves are presented in Table 1, and the identified species in Table 2. These groups are not in a taxonomic hierarchy equal, but they are common for many subterranean habitats.

In all five caves we found 12 groups of invertebrates (Table 1). This is remarkable level of biodiversity in underground habitats, and can be explained with the great diversity of microhabitats in the unsaturated layers. Ungurului cave in Romania was the richest in groups of taxa (11) and individuals (355) among the all sampled caves and also seasonally. Planina cave (Fig. 2 a) was the second richest cave with 10 groups of animals (Table 1). A total of 345 invertebrates were found in drips. Except larvae of Insecta that were presumably washed from the surface, Harpacticoida was the most abounded group, representing more than $30 \%$ of the total number of individuals. In Postojna cave (Fig. 2 b) 8 animal groups were found, including terrestrial species of Acarina, Collembola and Insect larvae (Diptera). Among aquatic species stygobi- onts of Copepoda prevailed (Tables 1 and 2), followed by Oligochaeta, Turbellaria and Nematoda.

For Romanian samples (Fig. $2 \mathrm{c}$-e) the results were different among sampling stations and among caves. In Ungurului cave 11 groups of animals were identified: Nematoda, Planaria, Gastropoda, Oligochaeta, Araneae, Acarina, Cyclopoida, Harpacticoida, Amphipoda, Collembola, Insect larvae. Of the total of 355 individuals most of them were harpacticoids (145) and oligochets (70). Six fauna groups have representatives in Vântului samples: Nematoda, Cyclopoida, Harpacticoida, Acarina, Collembola, Insect larvae. Best represented, in one station and one sampling were nematodes. In Vadu-Crișului cave representatives of 5 fauna groups were identified: Gastropoda, Cyclopoida, Harpacticoida, Amphipoda, Collembola, poorly represented. Most of the individuals were harpacticoids.

The same fauna groups are represented in percolation water of both countries, except Ostracoda, which 
Table 1: List of taxa and abundance of individuals collected in five caves in Slovenia and Romania

\begin{tabular}{|l|c|c|c|c|c|c|}
\hline \multirow{2}{*}{ Animal group/Cave } & \multicolumn{2}{|c|}{ Slovenia } & \multicolumn{3}{c|}{ Romania } & \multirow{2}{*}{ Total (\%) } \\
\cline { 2 - 7 } & Postojna & Planina & Ungurului & Vântului & Vadu-Crişului & \\
\hline Turbellaria & 3 & & 19 & & & 2.8 \\
\hline Nematoda & 2 & 48 & 6 & 25 & & 10.3 \\
\hline Gastropoda & & 8 & 5 & & 1 & 1.8 \\
\hline Oligochaeta & 4 & 28 & 70 & & & 12.9 \\
\hline Araneae & & 1 & 1 & & & 0.3 \\
\hline Acarina & 2 & 7 & 18 & 2 & & 3.7 \\
\hline Ostracoda & & & 1 & & & 0.1 \\
\hline Cyclopoida & 6 & 16 & 28 & 7 & 2 & 7.5 \\
\hline Harpacticoida & 5 & 115 & 145 & 1 & 7 & 34.6 \\
\hline Amphipoda & & 1 & & & 1 & 0.3 \\
\hline Collembola & 9 & 2 & 10 & 1 & 2 & 3.0 \\
\hline Insect larvae & 7 & 119 & 52 & 2 & & 22.8 \\
\hline
\end{tabular}

was identified in one Romanian cave (Ungurului), in a single sample. A rather rare finding in this habitat is one amphipod stygobiont in Vadu-Crişului cave (Niphargus sp.) and in Planina cave. For Planina cave it is known that an endemic stygobiont Niphargobates orophobata (Sket 1981) was found in dripping water. Although it is not clear yet what causes the differences among drips in fauna composition, this suggests that the unsaturated zone can represent a unique ecological niche. Non-stygobiotic fauna may accidentally reach subterranean habitats and often cannot survive there for a long time, but may be an important source of nutrients in a cave.

Results on subterranean aquatic fauna from Ungurului and Vântului caves are published for the first time, although studies were done in the last decades (Pleşa \& Iepure unpublished). The groups of animals we found in percolating water are generally adapted to the interstitial habitats, already known from other subterranean habitats in some of the studied caves (Pleşa 1969, Pleşa \& Racoviță 1973, Pleşa et al. 1996). Two strictly stygobiotic cyclopoid species have been found in trickles in three Romanian caves: Speocyclops troglodytes (Chappuis 1923) in Vadu Crişului and Vântului caves and Acanthocyclops reductus (Chappuis 1925) in Ungurului cave. In general, trickles provide a lower number of individuals than the associated pools, of both cyclopoids and other invertebrates. With the exception of Speocyclops troglodytes from Vântului cave sampled in trickles near the entrance, the species of the other two caves were reported in the sampled drips located between $300-500 \mathrm{~m}$ away from the entrance. Both mentioned species are rare in the karst area of the Western Carpathians, being recorded until now from pools and deep phreatic aquifers (Chappuis 1925,
Plesa 1965, Plesa et al. 1996). Although, Speocyclops troglodytes is a cosmopolitan stygobiont widespread in various groundwater habitats throghout Europe, in Romania this species has been recorded by now from only three caves of Western Carphatians. A. reductus has been reported from other two caves in Western Carpathians.

Table 2: The identified species of Copepoda Cyclopoida (C) and Harpacticoida $(H)$ in the studied caves

\begin{tabular}{|l|l|}
\hline Cave & Species \\
\hline \multirow{3}{*}{ Postojna } & Speocyclops infernus (C) \\
\cline { 2 - 2 } & Parastenocaris n. sp. (H) \\
\cline { 2 - 2 } & Bryocamptus balcanicus (H) \\
\cline { 2 - 2 } & Moraria poppei (H) \\
\cline { 2 - 2 } & Nitocrella n. sp. (H) \\
\hline \multirow{2}{*}{ Ungurului } & Acanthocyclops reductus (C) \\
\hline Vântului & Speocyclops troglodytes (C) \\
\hline Vadu-Crişului & Speocyclops troglodytes (C) \\
\hline
\end{tabular}

On the other hand, some differences were observed for each of the studied area, among caves and among stations in each cave, in terms of different copepod species and of different fauna assemblages. Seasonal or even monthly differences were also observed. Although in each country the studied caves are very close to each other, and no apparent differences at the surface geomorphology can be observed, differences in fauna assemblages indicate the heterogeneity of the shallow subterranean habitats (including epikarst), already mentioned for other subterranean habitats. 
(a)

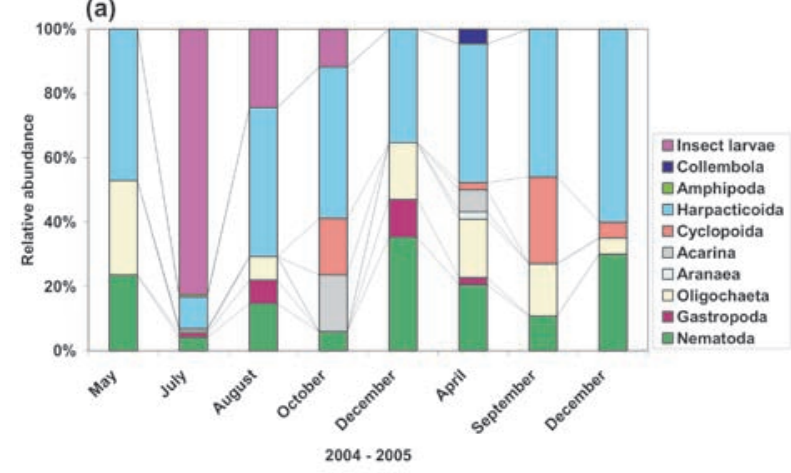

(c)
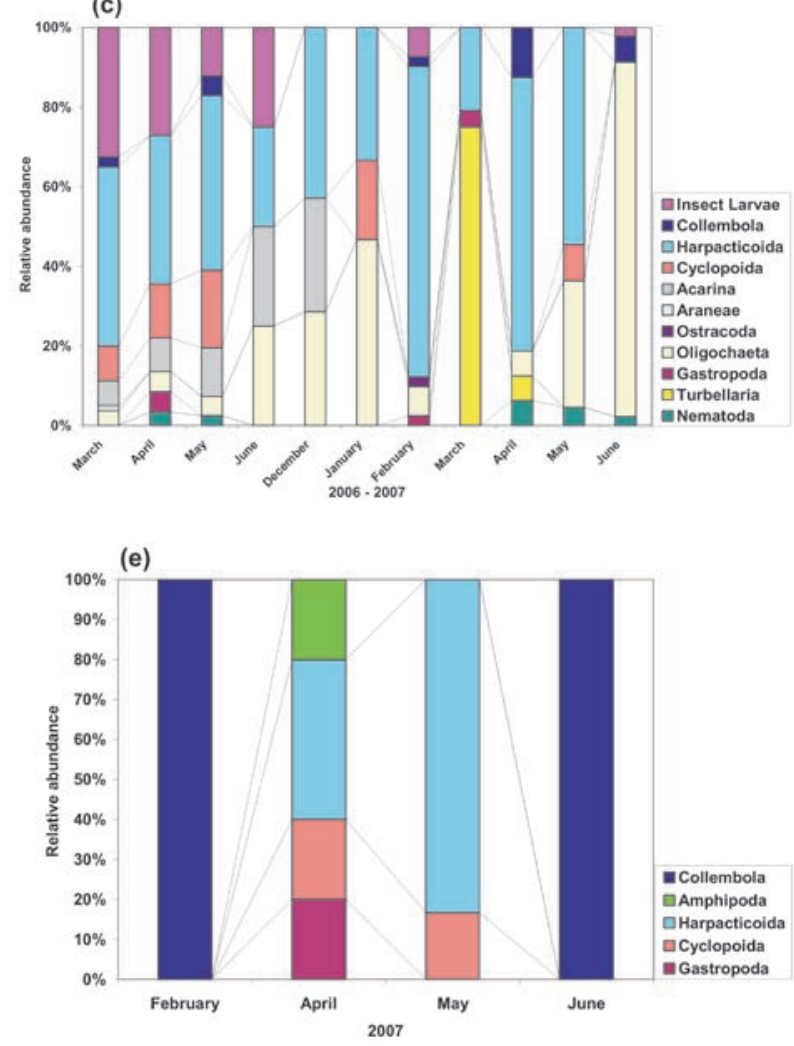

(b)

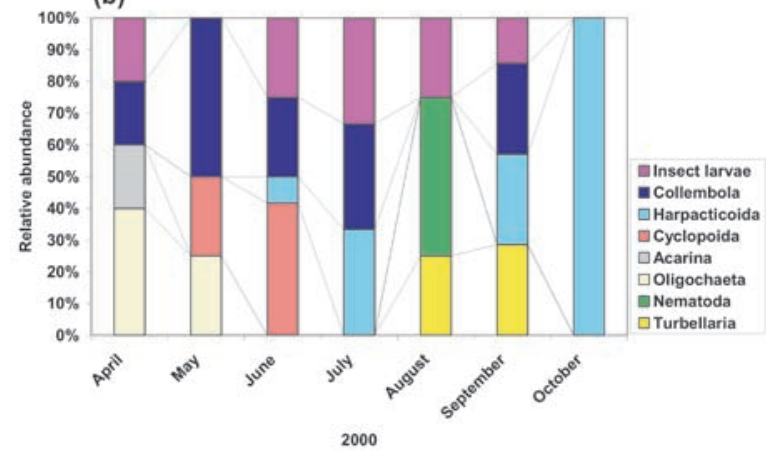

(d)

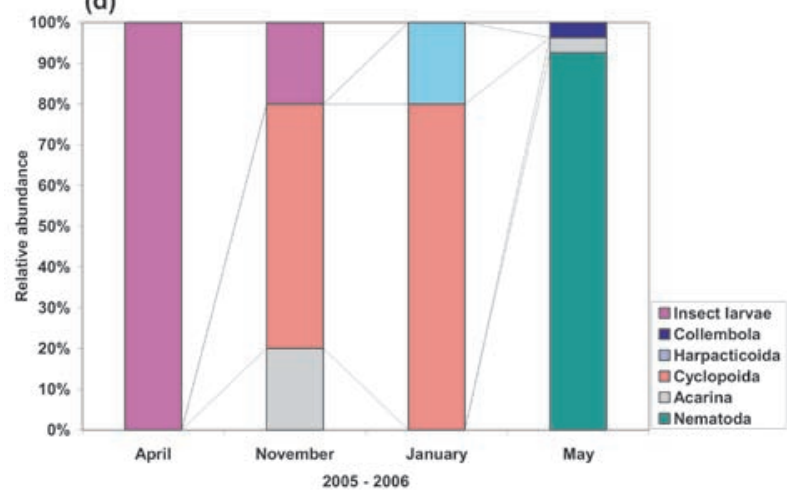

Fig. 2: Relative abundance of fauna groups in percolation water of the studied caves: (a) Planina, (b) Postojna, (c) Ungurului, (d) Vântului, (e) Vadu-Crişului (samples without fauna and periods of dryness are not presented).

The measured physico-chemical parameters (temperature, $\mathrm{pH}$, conductivity) shown in Table 3 are emphasized by the results of the canonical correpondence analysis in Figure 3. The measured parameters are defined mostly by the F1 axis ( $62 \%$ significance). Ordination of the fauna is related to the tem-

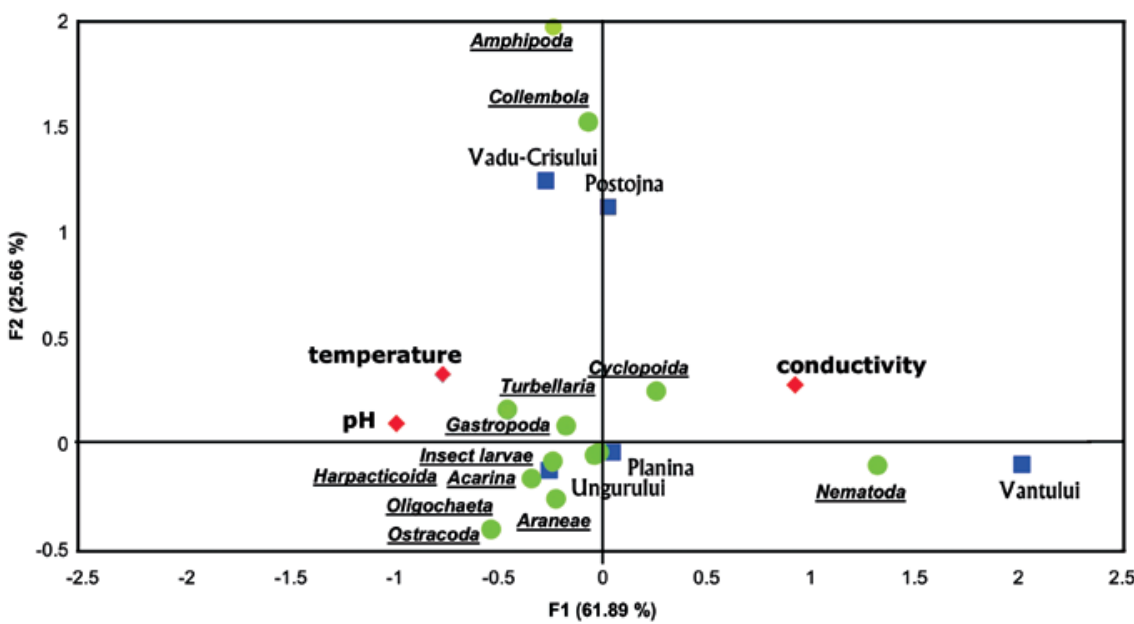
perature and $\mathrm{pH}$ in Postojna, Planina, Vadu-Crișului and Ungurului caves, and to the conductivity in the Vântului cave, which is negatively correlated to the two before mentioned

Fig. 3: Canonical correspondence analysis based on fauna groups (green dots) and physico-chemical parameters (red romboids) of the percolating water in five studied caves (blue squares) (see also Tables 1 and 3). 
Table 3: Basic environmental parameters of sampled drips in Slovenia and Romania

\begin{tabular}{|c|c|c|c|c|c|c|}
\hline \multicolumn{2}{|l|}{ Parameter / Cave } & \multirow{2}{*}{$\begin{array}{c}\text { Postojna } \\
9.02\end{array}$} & \multirow{2}{*}{$\begin{array}{c}\text { Planina } \\
8.99\end{array}$} & \multirow{2}{*}{$\begin{array}{c}\text { Ungurului } \\
9.20\end{array}$} & \multirow{2}{*}{$\begin{array}{c}\text { Vântului } \\
7.70\end{array}$} & \multirow{2}{*}{$\begin{array}{c}\text { Vadu-Crişului } \\
11.40\end{array}$} \\
\hline Temperature $\left({ }^{\circ} \mathrm{C}\right)$ & mean & & & & & \\
\hline & SD & 0.45 & 3.24 & 2.59 & 1.31 & 0.60 \\
\hline & $\min$ & 7.30 & 2.40 & 4.40 & 5.40 & 10.20 \\
\hline \multirow[t]{5}{*}{$\mathrm{ph}$} & $\max$ & 10.70 & 12.80 & 15.20 & 8.60 & 12.50 \\
\hline & mean & 7.80 & 7.68 & 7.80 & 7.00 & 7.80 \\
\hline & SD & 0.18 & 0.53 & 0.82 & 0.80 & 0.23 \\
\hline & $\min$ & 7.40 & 6.53 & 6.40 & 6.30 & 7.40 \\
\hline & $\max$ & 8.70 & 8.22 & 8.30 & 8.30 & 8.10 \\
\hline \multirow[t]{4}{*}{ Conductivity $\left(\mu \mathrm{Scm}^{-1}\right)$} & mean & 360.40 & 343.54 & 321 & 484 & 423 \\
\hline & SD & 56.09 & 65.17 & 116.15 & 157.50 & 65.70 \\
\hline & $\min$ & 215.00 & 214.00 & 127 & 286 & 303 \\
\hline & $\max$ & 465.00 & 464.00 & 568 & 630 & 574 \\
\hline \multirow[t]{4}{*}{ Drip rate $\left(\mathrm{mlmin}^{-1}\right)$} & mean & 7.03 & 12.79 & & & \\
\hline & SD & 14.16 & 23.07 & & & \\
\hline & $\min$ & 0.50 & 0.20 & & & \\
\hline & $\max$ & 156.00 & 88.00 & & & \\
\hline
\end{tabular}

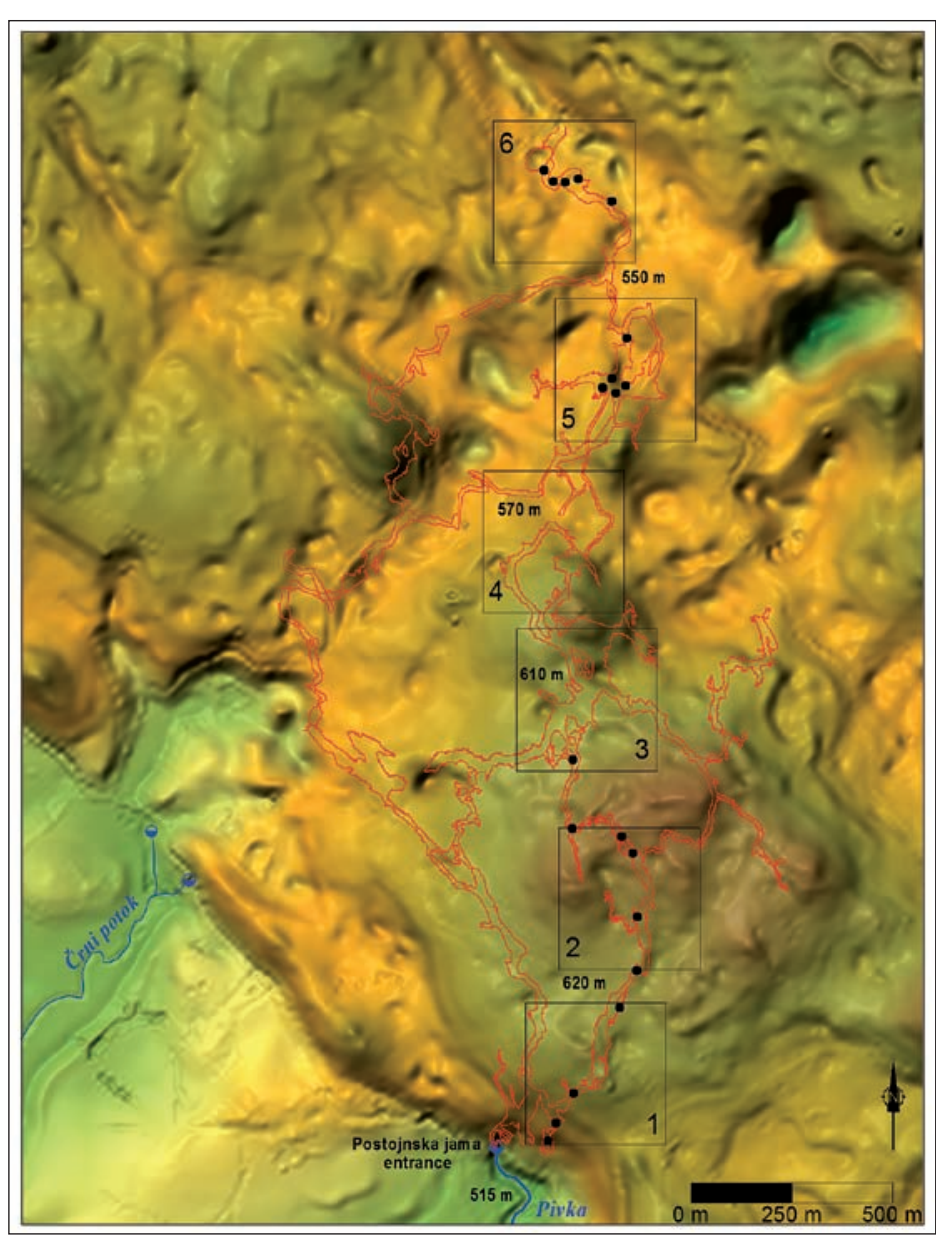

parameters (temperature, $\mathrm{pH}$ ). The presence of nematodes can be also related to the high conductivity and is probably due to pollution from the surface.

Correlation of abundance among sampling sites and drip rates (mlmin-1) was slightly significant in the Planina cave $\left(\mathrm{r}_{\mathrm{s}}=0.5 ; \mathrm{p}<0,002\right)$ while not in the Postojna cave.

For the Postojna cave system we obtained relatively significant correlation ( 0.71$)$ between the surface area of dolinas (Fig. 4) and the abundance of fauna in percolation water in corresponding station(s). It can be explained by the importance of dolinas for water accumulation and continuous release underground, which ensures the permanent drift of animals inside the caves.

Fig. 4: The projection of Postojna cave system (in red) and the frames (1-6) defined for the calculation of dolinas' surface. Black dots represent sampling points for percolation water fauna inside the system. 


\section{DISCUSSION AND CONCLUSIONS}

This study provides insights in the knowledge about fauna in percolation water from five Slovenian and Romanian caves. Romanian long-term investigations of this habitat are published for the first time and thus, new ecological information was obtained for the studied area. Although belonging to different karst regions (Slovenian Classical Karst and Western Romanian Carpathians), with different characteristics and fauna composition, some similarities were observed. The same fauna groups can be observed in this habitat. Such groups have representatives adapted to life in small volumes, as the interstices in the unsaturated zone of the caves.

Differences between caves and sampling points can have various explanations, such as degree of fracturisation, cavernosity, epikarst development, land use, surface (soil) and subsurface (unsaturated zone) capacity for water storage, presence/absence of pollutants etc. The importance of the surface landforms, as dolinas, can be determinant in the case of Postojna cave system. For the moment we can not sustain one or another of these hypotheses, because further and additional information are needed. New directions for further researches must be proposed, and beside biological studies information about chemistry of the water, geomorphology, geology, hydrology are necessary to complete our view about epikarst and vadose zone fauna.

Culver (2003) emphasizes the importance of subsurface habitats, including epikarst, in cave colonization. Fauna from unsaturated layers, as epikarst and vadose zone, are introduced by percolating water in subterranean basins, lakes and rivers. This has been proven, but what we want to stress on is the problem of active colonization of fauna in percolating water, in the frame of the active colonization model proposed by Rouch \& Danielopol (1987). Active colonization is possible through active drifts that can be defined as the behaviourally controlled downstream displacement of animals as an adaptation to escape predation, or to colonize new sections of a river. The concept of drift was firstly introduced by Needham (1928), but drift attracted more attention after the 1950s. Excepting stygophiles and stygoxenes, which can be in- deed accidentally washed inside the caves, stygobiont horizontal and vertical movements can be actively determinated by factors as population growth or even predation. Periods of intense percolation are not necessarily correlated with high abundance and high biodiversity, as shown in the correlation between drip rates and number of individuals. Drift could be the best way of deep underground colonization of aquatic fauna especially in areas where there is no organised inflow from the surface. There is a strong need of taxonomic work for all the collected material in order to sustain our assumption of an active colonization of cave habitats by fauna from unsaturated layers.

The epikarst and vadose habitats are highly vulnerable. Both hold a considerable reservoir of subterranean water and harbor exceptionally rich copepod fauna with a high frequency of endemism that particularly increases conservation value of the epikarst and karst area as a whole (Pipan 2005). Study of the unsaturated zone represents a powerful tool for understanding environmental effects on groundwater fauna. The study of the fauna in percolation water of selected caves in Slovenia and Romania can serve as a model for subterranean fauna in general.

Results of this work increase our understanding of ecology in the epikarst and deeper unsaturated zone. In particular, this research contribute to the characterization of geomorphologic and biologic processes in the karst aquifers and knowledge that is valuable for future pollution control efforts not just in Classical Karst in Slovenia and Western Carpathians in Romania but in karst terrains worldwide. From a biological perspective, very little work has been done investigating the unsaturated zone fauna worldwide and our results contribute to the state of current knowledge about this fauna. In a future perspective we will use our results to support the design and implementation of studies at larger scales, with the ultimate goal to understand better how small scale processes in the unsaturated layers are responsible for the quality of water in a karst aquifer.

\section{ACKNOWLEDGEMENT}

Authors are grateful to David C. Culver and Dan L. Danielopol for revision of the English text and helpful comments on an earlier version of the manuscript. Romanian authors are grateful to Andreea Oargă and Grațiela Stur- za for help during sampling, Bogdan Onac for geological information, and the custodians of the Vântului cave and the administrations of the Ungurului (Speleological Club CSA) and the Vadu-Crişului (the "Țării Crişurilor” Mu- 
seum) caves. This study was funded by the Ministry of Higher Education, Science and Technology of the Republic of Slovenia, the Slovenian Research Agency (project no. BI-RO/05-06/001), and by the Ministry of Educa- tion and Research, Department of European Research Programs in Romania (MCT project no. C18446/2006) and grant 1150/2007 of the National University Research Council.

\section{REFERENCES}

Camacho, A. I., A. G. Valdecasas, J. Rodríguez, S. Cuezva, J. Lario, \& S. Sánchez-Moral, 2006: Habitat constraints in epikarstic waters of an Iberian Peninsula system cave.- Annales de Limnologie-International Journal of Limnology, 42, 2, 127-140.

Chappuis, P.A., 1925: Sur les Copépodes et les Syncarides des eaux souterraines de Cluj et des Monts Bihar.Bulletin de la Société de Sciences de Cluj, 2, 157182.

Culver, D. C. \& Sket B., 2000: Hotspots of subterranean biodiversity in caves and wells.-Journal of Cave and Karst Studies, 62, 11-17.

Culver, D. C., 2003: Epikarst from an ecological and evolutionary perspective: suggestions for future research. In: Jones, W. K., D. C. Cuver, \& J. S. Herman (eds.) Proceedings of the "Epikarst" Symposium, October 1-4, 2003, Sheperdstown, West Virginia, USA, Karst Waters Institute Special Publication 9, pp. 127-131.

Delay, B., 1968: Données sur le peuplement de la zone de percolation temporaire.- Annales de spéléologie, 23, 4, 705-716.

Needham, P. R., 1928: A net capture of stream drift organisms.- Ecology, 9, 339-342.

Petrič, M., 2002: Characteristics of recharge-discharge relations in karst aquifer.- Inštitut za raziskovanje krasa ZRC SAZU, Založba ZRC, p. 154, Postojna - Ljubljana.

Pipan, T., 2003: Ecology of copepods (Crustacea: Copepoda) in percolation water of the selected karst caves.- Doctoral Dissertation (in Slovene with English abstract and summary), University of Ljubljana, Dept. of Biology, p. 130, Ljubljana.

Pipan, T., 2005: Epikarst - A Promising Habitat. Copepod fauna, its diversity and ecology: a case study from Slovenia (Europe).- Karst Research Institute at ZRC SAZU, ZRC Publishing, p. 101, Postojna - Ljubljana.

Pipan, T., \& Culver, D. C., 2005: Estimating biodiversity in the epikarstic zone of a West Virginia cave.- Journal of Cave and Karst Studies, 67, 2, 103-109.
Pipan, T., M. C. Christman, \& D. C. Culver, 2006: Dynamics of epikarst communities: microgeographic pattern and environmental determinants of epikarst copepods in Organ Cave, West Virginia.- American Midland Naturalist, 156, 75-87.

Pipan, T., \& Culver, D. C., 2007: Epikarst communities: biodiversity hotspots and potential water tracers.Environmental Geology, 53, 265-269.

Pleşa, C., 1969: Researches on reproductive periodicity at some cave troglobiontic Crustacea (in Romanian in original). -Doctoral thesis, "Traian Săvulescu" Biological Institute of the Romanian Academy, București, $180 \mathrm{pp}$.

Pleşa, C., O. Moldovan, \& A. Munteanu, 1996: Aperçu biospéologique sur la Grotte de Vadu-Crişului, Monts Pădurea Craiului (Transylvanie, Roumanie).Travaux de l'Institut de Spéologie "Emil Racovitza", $35,115-142$.

Pleşa, C., M. Pintea-Alb, M. Sălăjan, \& F. Wild, 1965: Date noi asupra ecologiei şi răspândirii geografice a ciclopidelor (Crustacea, Copepoda) în România.Lucrările Institutului de Speologie «Emil Racoviță», 4, 141-154.

Pleşa, C., \& G. Racoviță, 1973: Recherches sur les gours, en tant que milieux aquatiques souterrains. Note I. In: Livre du cinquantenaire de L'Institute de Spéologie "Emile Racovitza", Academia R.S.R, București, pp. 487-502.

Rouch, R., 1968: Contribution à la connaissance des harpacticides hypogés (Crustacés - Copépodes).Annales de spéléologie, 23, 1, 5-167.

Rouch, R., \& D. L. Danielopol, 1987: Lorigine de la faune aquatique souterraine, entre le paradigme du refuge et le modèle de la colonisation active.- Stygologia, 3 (4), 345-372.

Sket, B., 1981: Niphargobates orophobta n.g., n.sp. (Amphipoda, Gammaridae s.l.) from cave waters in Slovenia (NW Yugoslavia).- Biološki vestnik, 29, 1, 105-118. 
Sket, B., P. Trontelj, \& C. Žagar, 2003: Speleobiological characterization of the epikarst and its hydrological neighborhood: its role in dispersion of biota, its ecology and vulnerability. In: Jones, W. K., D. C. Cuver, \& J. S. Herman (eds.) Proceedings of the "Epikarst" Symposium, October 1-4, 2003, Sheperdstown, West Virginia, USA, Karst Waters Institute Special Publication 9, pp. 104-113.

Šebela, S., 1995: Geološke osnove oblikovanja največje podorne dvorane v Postojnski jami-Velike Gore.Annales, 7, 95, 111-116, Koper.
Trček, B., 2003: Epikarst zone and the karst aquifer behaviour. A case study of the Hubelj catchment, Slovenia.- Geološki zavod Slovenije, p. 100, Ljubljana.

Williams, P. W., 1983: The role of the subcutaneous zone in karst hydrology.- Journal of Hydrology, 61, 4567. 
